VII. The genus Criocephalus. By D. Sharp, M.A., F.R.S.

With Notes on the habits of Asemum striatum and Criocephalus ferus. By F. Gilblert Smith.*

\title{
Plate IX.
}

IN the Munich Catalogue of Culeoptera (vol. ix, 1872, p. 2789) Criocephalus is allotted ten species. Another species has since been added by Herr Edmond Reitter, C. syriacus, Wien. Ent. Zeit., 1895, p. 86 . C. coriaceus, Motsch., must be rejected as the description is totally worthless (cf. p. 158), and no type is known. C. mexicanus, Thoms., is treated as a synonym of C. obsoletus.

Great confusion has always existed as to the species, and there are numerous errors in the Munich Catalogue. A revision of the genus will therefore be useful as a step towards the attainment of further knowledge.

I owe my thanks to Mr. Gahan for assisting me in the examination of the specimens in the British Museum, and to M. Réné Oberthür, Herr Edmond Reitter, M. Louis Bedel, Mr. G. C. Champion, and Mr. George Lewis for the communication of specimens.

\section{Distribution.}

The genus Criocephalus is distributed over the Northern hemisphere, occurring in about equal numbers in the Old and New Worlds; it does not pass the equator, and scarcely touches the tropics, except in the highlands of their northern parts. This distribution is probably chiefly determined by the distribution of coniferous trees, to which it is believed the species of Criocephalus are confined, their food being found in the wood of these trees. C. rusticus has a natural dístribution probably as wide as that of any other Coleopterous insect, it is found from Norway to

* Although Mr. Smith has not had any part in actually drawing up the systematic part of this paper, I have received very important assistance from him in this matter. He first noticed the peculiarity of the deficient spur in the group. The notes on the larvæ have been made by us conjointly. I, of course, have hal no part in Mr. Smith's account of his observations in the field. -D. S.

TRANS. ENT. SOC. LOND. 1905. -PART I. (MAY) 10 
Algeria, and in the other direction to Japan, and even in Yunnan. It is probably occasionally carried about with timber, but this cannot have much affected its wide distribution. There is no reason for supposing that any of the other species are increased in the area of their distribution by commercial means, as timber is not imported into most of the countries in which the species live.

\section{TAXONOMY.}

Criocephalus has been placed in the group Aseminx of the great subfamily Cerambycides, a group of only a few genera, but as to the composition of which systematists have very widely differed. Lacordaire (Gen. Col., viii, p. 205, as Asemides) assigns to it five genera, Asemum, Nothorhina, Cyamophthalmus, Tetropium, Criocephalus. Thomson (Syst. Ceramb., p. 463, as Asemitre) places in it nine genera, excluding Tetropium, but adding five other European genera. Leconte and Horn (Class. Col. N. Amer., ed. ii, 1883, as Asemini) adopt Lacordaire's view, Cyamophthalmus being, however, unknown to them; and the same remark applies to Schiödte (Danmark's Ceramb., p. 507, as Asemini), who also did not include Nothorhina. Duval (Gen. Col. Eur. Céramb., p. 125, as Criocephalites) associated Criocephalus, Cyamophthalmus, Tetropium, placing Asemum and Nothorhina in a distinct group (Asemites). Ganglbauer and Bedel, who have, each one, published an excellent work on the European Cerambycidæ, have not dealt at all with the question of minor groups. Kraatz has recently added the genus Megasemum (Berlin. Ent. Zeitschr., 1879, p. 97) without, however, giving any character that would distinguish the genus from Criocephalus.

On examination it appears that none of the genera hitherto associated with Criocephalus are closely allied to it, except Megasemum. Criocephalus possesses the very exceptional character of having only one spur on the front tibia, while the other genera usually associated with it have two.

Criocephalus syriacus, Reitt., is here made a distinct genus, Cephalocrizis; it and Megasemum agree with Criocephalus in the unicalcarate tibia and are extremely closely allied to it.

Megasemum was distinguished by Kraatz solely on the strength of shorter antennæ. This however does not hold 
good for the male which has longer antennæ.* Even in the female the antennæ are not shorter than they are in the N. American Criocephalus asperatus, to which species Megasemum has a great resemblance. Megasemum differs however in the form of the prosternum, which is concave in profile instead of convex as in certain Criocephalus, or flat as in other species. It has moreover the clypeus much more elongate, the antennæ more distant from the mandibles and the eyes not extended to the under-surface of the head.

I describe also a new genus, Cephalallus, that is closely allied to both Megasemum and Criocephalus. The four genera in question form a natural group to be called Criocephaline, distinguished from the Aseminx by the presence of only one spur on the front tibiæ.

The four genera of Criocephalinæ may be distinguished as follows-

(1) Criocephalus. Terminal joint of palpi only moderately broad at tip; prosternum protuberant in front, or flat; clypeus short.

(2) Cephalocrius. Terminal joint of palpi very broad at the apex; prosternum nearly flat; clypeus very short.

(3) Megasemum. Terminal joint of palpi only moderately broad; prosternum slightly descending; eyes not extended on under-surface of the head.

(4) Cephalallus, n. g. Terminal joint of palpi not very broad at tip; prosternum descending; eyes extending to under-surface of the head.

The Criocephalina should come at the beginning of the subfamily Cerambycides, as being one of the most primitive forms of Longicorn Coleoptera. The only other genus of Longicorns that I have found to agree with Criocephalinx as to the unicalcarate tibiæ is the genus Philus, which forms an annectant link between Cerambycides and Prionides. This character is not to be looked on as primitive. The primitiveness of Criocephalus depends not on such points as this, but on the fact that it differs but

* The male of Megasemum has not yet been described. It is similar to the female but has the antennæ longer and much more hairy. I have seen only one specimen of this sex, it is in the British Museum Collection. For my knowledge of the female I am indebted to Mr. George Lewis, who met with the species in Japan. 
little from Coleoptera of other families; that it lacks all the specializations that are so remarkable in other divisions of Longicorns, while but little changes would suffice to make it a member of other divisions, either of Cerambycides or of Prionides.

Cephalallus, n. g.

Caput brevissimum.

Palpi perbreves, articulo ultimo modice dilatato.

Oculi magni, subtus conspicui.

Prosternum descendens, parum elongatum.

I have only a single example, of the female sex, and in a very mutilated state, before me; but it represents a species of so much interest that I do not hesitate to name it and call attention to it.

A slight modification of the prosternum of this insect would transform it into a Criocephalus, while an elongation of the head would apparently make it a Megasemum.

The labrum is small and has a pencil of hairs near the front as in Criocephalus ferus. Mandibles extremely short, each with a single, strong tooth in the middle. Palpi very short, the terminal joint only slightly, but still distinctly, dilated at the tip. Ligula extending on each side as far as the middle of first joint of labial palpus. Eyes convex, extending on to the under-surface of the head, but widely separated there as in Criocephalus rusticus.

Prosternum margined in front; behind the margin extending obliquely downwards; only very slightly separating the front coxæ. Metasternum elongate, terminal segment of the female less elongate than in Criocephalus. Hind femora hairy behind, but not densely so.

If the genus be not maintained as distinct it will be necessary to unite Megasemum and it with Criocephalus.

\section{Cephalallus oberthüri, sp. n.}

ๆ. Elongatus, angustus, convexus, piceus, elytris ferr.gineis; prothorace angusto, convexo, asperato, sculpturato, peropaco, medio late leviter impresso; elytris dense fortiter punctatis, subtiliter, sex-costatis. Long. $22 \mathrm{~mm}$.

Hab. Tsekou in North Yunnan. (Coll. R. Oberthür.)

The general form is that of a narrow Criocephalus, but from all the forms of that genus it is distinguished by the very dense punctuation of the elytra, which renders them 
finely rugose. The eyes bear a few fine but moderately long setæ between the facets. The clypeal suture is very deep, and forms an acute angle in the middle. The thorax is a good deal narrower than the elytra, and only slightly broader than the head and eyes; it is scarcely transverse, but is convex transversely, it bears numerous sharp, elevated granules, between which it is minutely rugose, and has some fine hairs; there is a vague, broad depression on the disc, and behind this a feeble prominence in the middle just in front of the scutellum. The elevated lines on each elytron are not very distinct, the two on the middle do not reach the apex, and the lateral one cannot be seen either at the base or apex, the sutural angle is minutely spinose.

The legs and antennæ are very mutilated; all that remains of the former are some portions of femora, and one front tibia. Six joints remain of one antenna: these are rather slender, and bear numerous erect hairs; the first joint is rather more than twice as long as the second; the third is not quite three times as long as the second, the fourth is about as long as the first, the fifth is shorter than the fourth, and the sixth shorter than the fifth and but little longer than the first.

\section{Cephalocrius, n. g.}

Antennæ fere corporis longitudine, longius hirtellæ.

Palpi articulo ultimo ad apicem latissimo.

Type Criocephalus syriacus, Reitter.

Closely allied to Criocephalus, the C. syriacus of Reitter is well distinguished by the above characters. I have seen only one example and am not able to describe the parts of the mouth more fully. Herr Reitter informs me that in the female the antennæ are less hairy than they are in the male. The really important character of the genus is the form of the palpi.

\section{Cephalocrius syriacus, Reitter.}

Criocephalus syriacus, Reitter, Wien. Ent. Zeit., 1895, p. 86.

屯. Angustus, subdepressus, ferrugineus, elytris bicostatis et crebre punctatis, antennis corporis longitudine subtus hirsutis; tarsis posterioribus articulo tertio profunde fisso, articulo basali elongato. Long. vix 15 , lat. $3 \frac{3}{4} \mathrm{~mm}$. 
This is very distinct by the strongly dilated terminal joint of the palpi which is broadly securiform, both on the maxilla and labium. The hind tarsi are long and slender, with remarkably long basal joint. The eyes are rather more prominent and have a greater extension on the under-surface of the head than they have in $C$. rusticus. The sculpture of the gular area is transversely rugose, the impressed punctures not numerous. This insect was kindly sent home by Herr Reitter with the locality "Syria." In his description he mentions, Haifa, Akbès. There is also a male example from Akbès in the Oberthür Collection.

N.B.-The British Museum Collection contains a specimen of this genus from the collection of Dejean. It is in very bad condition, and I do not know whether it is C. syriacus or another species. In Dejean's collection it was labelled "rusticus, Gall. mer." The locality from which this specimen really came is, I consider, extremely doubtful.

\section{Criocephalus, Mulsant.}

Criocephalus (Dej.), Muls. Longicornes, ed. i, p. 63.

I have already mentioned the characters that distinguish this genus from the allied forms (p. 147).

The species present a great uniformity of appearance and as they are fairly numerous it is not easy to distinguish them. Particular attention should be given to the form of the thorax, the length of the small setæ between the facets of the eyes, and the form of the third joint of the tarsus.

The genus has been subdivided by the eyes being "hairy" or "bare." But this is incorrect; all the species have some setæ between the ocular facets, and it is only a question of longer or shorter. The same remark applies to the lobing of the third joint of the tarsus, which differs somewhat from species to species. The labrum apparently offers a better character, but unfortunately it is not easy to see without opening the mandibles and this it is somewhat difficult to do, as they are closed by very powerful muscles, which cannot be ruptured after the insects are dead and dried.

\section{Group A.}

Labrum without pencil of hairs in fovea on the middle of its area. Eyes with long hairs between the facets. 


\section{Criocephalus Deceptor, sp. $\mathrm{n}$.}

Depressus, fusco-niger, breviter griseo-pubescens, opacus ; thorace fortiter transverso; elytris bicostatis fortiter punctatis. Long. $20 \mathrm{~mm}$.

This species is an extremely distinct one, though it looks at first sight very like a moderately-sized individual of C. rusticus. It is however more depressed than that species, and this character removes it from all the other described species.* From C. rusticus, $C$. deceptor differs strongly by the tarsal structure, the third joint being only slightly lobed. The unique specimen is much damaged; the prosternum is not in the least degree protuberant or convex, and the under-surface is remarkably flat. The labrum is of the type of that of $C$. rusticus.

Hab. Western Tibet, one specimen in the collection of the British Museum,

\section{Criocephalus rusticus, Dej.}

Brunneo-ferrugineus, vel fusco-niger, subplanatus, elytris sat discrete bicostatis, inter costas perspicue punctatis; prothorace transverso, ad latera fere regulariter rotundato, posterius plus minus angustato. Long. 14-30 mm.

The male has the basal portion of the antennæ, and the legs markedly thicker than the female.

The synonymy of this species, as distinguished from C. ferus, is very doubtful. Some of that given in the Munich Catalogue is taken from writers who did not distinguish the two forms. The C. rusticus of Dejean's Catalogue and collection is however certainly this species, as is also Mulsant's C. rusticus, and var. B., 1. c., p. 64. Also C. rusticus, Woll. Cat. Col. Madeira (1857), p. 124 (nec Col. Canar., for which see C. pinetorum).

The species is readily distinguished by the strongly transverse thorax, which is only one-fifth of the length of the elytra, and by the gular area being very indefinitely limited, rugose in front and feebly punctate behind, and with only a few suberect long hairs, forming a strong contrast to what exists in $C$. ferus. In finely-developed

* There is an undescribed (?) species in the collection of the British Museum, coming froin the Amanus mountains of Asia Minor, which is also very depressed; but in other respects this insect is very different from $C$. deceptor. 
specimens the sculpture of the gular area is more largely developed, there being both more rugæ and more punctures, but the sculpture always retains the same character. The setæ between the facets of the eyes are so long that they can be easily detected; the third joint of the tarsus is divided nearly to the base, and the lobes formed by the division are large and symmetrical. The scutellum is always a little impressed along the middle. The metathoracic epimera are comparatively narrow.

The species is very variable in size, form and sculpture, but after repeated examinations I fail to find any reliable character to separate even the most extreme forms. The length varies from $14-30 \mathrm{~mm}$. and the width from $4-7 \frac{1}{2} \mathrm{~mm}$. The female is generally larger than the male and is somewhat darker in colour, but is never quite black. There are sometimes three depressions on the thorax, and these in a few specimens are deep and well-marked. The sculpture of the upper-surface also varies : it is sometimes coarser and less dense, and the insect appears slightly shining. The elytra usually lave the tip-sutural angle sharp, or rectangular, but this also is variable. The rugæ on the gular area vary a good deal, but the sculpture there never has the character of definite depressed punctures, and it bears only an irregular, somewhat scanty pubescence, never the regular dense pilosity of the C. ferus group of species. The setosity on the labrum also varies.

I have examined the male organs in some of the most remarkable of the varieties and find they agree. The two closely appressed laminæ that form the tip of the introminent organ are not of equal length, but the lower one is the longer and is very sharp. In this respect $C$. rusticus differs from $C$. ferus.

I think it quite possible that careful study of a series of good examples of both sexes may show that there is really more than one species mixed under $C$. rusticus. I should recommend a thorough scrutiny of the labrum as likely to give good results, but this is unfortunately attended with great practical difficulties.

The species inhabits apparently all the temperate zone of the Old World in the Northern hemisphere, wherever there are suitable timbers; what species of conifer it may prefer I do not know; but doubtless the Scotch fir (Pinus sylvestris) is one of them. I have specimens before me from Norway (Champion); Hanover; Vienna; S. France; 
Spain, Bronchales, Tragacete, La Granja (Champion); Corsica, Vizzavona (Champion); Akbès (Coll. Oberthür); Amurland; Japan (Lewis); Tsekou in North Yunnan (Coll. Oberthür); and I have seen specimens from Madeira and other localities.

The species has recently been discovered by Colonel Yerbury at Nethy Bridge, near our wildest Highlands, where the Scotch fir is still extant in its natural state. The specimen he found was on a sprig of heather near a large stump of the Scotch fir. It is a fine fenale and is now in the collection at the British Museum.

This specimen is I think undoubtedly a native of Britain, and it is of importance as showing that the discovery for the first time of a Criocephalus in a locality is not sufficient evidence of its being an introduction. Mr. Gilbert Smith's extremely interesting notes on the natural history of C. ferus and Asemum striatum should also be considered in this connection. There can however be little doubt that this species is liable to be carried about; though probably this only occurs as an exception, even when large blocks of timber are transmitted. A specimen has been found in a coal-mine in Wales, where it was pretty certainly carried in the wooden props; and if foreign fir-wood be used for railway sleepers it may thu: be transmitted. The case recorded of its introduction by means of timber for masts must also be noticed.

C. rusticus was not known to Wollaston when he wrote the "Insecta Maderensia" (published in 1854), but it afterwards became common in the plantations of introduced fir-trees, and in 1857 was recorded by him in the category of "undoubtedly introduced" species. [The "C. rusticus" of the Canary Islands is C. pinetorum.] It appears to have spread with rapidity in the Madeiran group, as in 1865 Wollaston recorded it from the extreme summit of the small island called Dezerta Grande. But this must be received with some caution, as it is far from impossible that $C$. pinetorum occurs in Madeira as well as in the Canaries.

\section{Criocephalus coreanus, sp. $n$.}

. Fusco-niger, hand nitidus, antennis pedibusque piceis ; prothorace parum transverso, densissime rugoso-punctato, ad latera numerose muricato ; elytris costis duabus parum elevatis, punctisque impressis per-numerosis, Long, $22 \mathrm{~mm}$. 
In this species the thorax is about one-fourth the length of the elytra, whereas in C. rusticus it is about one-fifth. On measuring two specimens of about equal size I find them to be, C. coreanus: thorax $3 \frac{5}{8}$, elytra $15 \frac{1}{2} \mathrm{~mm}$. long. C. rusticus: thorax $2 \frac{7}{8}$, elytra $15 \mathrm{~mm}$., and these proportions persist (with some variation) in the individuals of different sizes of $C$. rusticus. The head and thorax of $C$. coreanus are also considerably narrower, and the antennæ more slender. The length of the thorax is $4 \frac{3}{8} \mathrm{~mm}$. The sculpture of this part is denser and finer than it is in C. rusticus, The scutellum is narrower than in $C$. rusticus, almost flat, with a slender polished line along the middle.

Although I have only one mutilated female of this form I have little doubt that it represents a species closely allied to $C$. rusticus but distinct. The structural characters appear to agree with those of $C$. rusticus. It should be noted that the Japanese form of $C$. rusticus is very different from $C$. coreanus.

\section{Criocephalus obsoletus, Randall.}

Criocephalus obsoletus, Leconte, J. Ac. Philad. ser. 2, II, p. 196 [= obscurus, id. p. 36].

Criocephalus mexicanus, Thomson, Classif. Longic. 1860, p. 260 ; Bates, Biol. Cent. Amer. Col., V, p. 15.

This species is extremely near C. rusticus, but will probably prove to be distinct. I have only one specimen at my disposal. The sculpture of the upper-surface is rather coarser. The thorax has a slight angulation at each side; the second joint of the antenna is a little longer, and the scutellum is broadly impressed.

$H a b$. N. AMerica : widely distributed and apparently not uncommon in Mexico, "in pine forests at the higher elevations."

I have followed Mr. Gahan, in his arrangement of the British Museum Criocephalus, in considering C. mexicanus of Thomson and Bates to be a synonym of $C$. obsoletus.

For remarks on the North American species generally see under $C$. nubilus.

\section{Group 2.}

Labrum with a pencil of hairs placed in a fovea in the middle near the front. 
N.B.- - I have not been able to examine the labrum in $C$. exoticus and $C$. tibetanus, and one or both may therefore prove not to belong to this division. Neither the hairs on the eyes nor the lobing of the tarsi can be used as sectional characters as there are intermediate conditions of both of them. But in this section the ocular setæ are usually short, and the basal lobes short.

\section{Criocephalus pinetorum, Woll.}

§. Criocephalus pinetorum, Woll., Journ. Entom. II, p. 103 (1863); and Cat. Col. Canar., p. 388 (1864).

․ Criocephalus rusticus, id. Col. Atlant., p. 345 (1865).

Wollaston first fell into the double error of considering the sexes of $C$. pinetorum to be different species and of determining the female to be $C$. rusticus. This was not recognized by him in revising the work in 1865 , and being then baffled to distinguish the $C$. pinetorum he sank the species as being merely $C$. rusticus, from which however it is totally distinct. This does not complete the sum of Wollaston's confusion; for he considered the Madeiran $C$. rusticus to be the same, though he noticed the different habitat in the two islands. The insect found about Funchal in Madeira in connection with the introduced, planted, conifers is really the C. rusticus of authors, while the C. rusticus of Wollaston Coll. Atlant. (nec auctt.), found in the native pinals of the Canary Islands, is the female of $C$. pinetorum, Woll., and is a quite distinct, precinctive species. As Wollaston found the two together in the Canaries it appears remarkable that he should not have considered them to be the sexes of one and the same species. Probably he suspected them to be so, but not having detected the characters that distinguish the female from $C$. rusticus and $C$. ferus (which at that time were generally confounded in collections), he finally came to the erroneous conclusion that all were one species. Hence this good species has since been lost sight of. Bedel however suspected some error; and in placing the name as a synonym of $C$. rusticus added a note of interrogation.

This species has the eyes bare (i.e. with extremely short setæ between the facets) and the fourth joint of the tarsi intermediate between that of $C$. rusticus and $C$. ferus. The sexes are very different, and hence Wollaston supposed 
the female to be $C$. rusticus. The female differs from the male by its large size, black colour, and the usual differences in the length of the antennæ and the structure of the apex of the abdomen.

"Abounds in the Ancient Pinals of intermediate and lofty elevations" (Woll. 1865), but nevertheless is excessively rare in collections. Recorded from the islands of Palma, Teneriffe, and Hierro.

The male is small (sometimes only 10 or $11 \mathrm{~mm}$. long) and of a brown colour, the gular area is very definitely limited behind, almost semicircular, and is closely and coarsely punctured, the bush of erect pubescence moderately dense.

The female has not been described. I have seen only two specimens of it, one in my own collection and one in Wollaston's Canarian collection, where it stands as $C$. rusticus. It is more flat than the corresponding sex of $C$. ferus, and has a more transverse thorax. The punctuation of the gular area is remarkably definite, and extends over a large space ; the prosternum is but little convex in front, and the metathoracic episternum is much narrower. In these latter respects, as well as in the more deeply divided third tarsal joints, it approaches C. rusticus.

\section{Criocephalus ferus, Mulsant.}

Transversim convexus ; mas fusco-niger, femina nigricans ; opacus, elytris bicostatis, inter costas tantum subtilissime punctatus. Long. $10-30 \mathrm{~mm}$.

The male is usually shorter and paler in colour than the female and the prosternum is much less convex. This species is rare in collections, and owing to this and to the want of knowledge as to the sex-differences are due its confusion with $C$. rusticus by entomologists. The two forms are really profoundly different. The structure of the labrum distinguishes the two absolutely, but there are numerous other characters. In the male of $C$. ferus the basal portion of the antennæ is but little thicker than in the female. In the female the front of the prosternum is more convex, and the metathoracic episterna considerably broader than in C.rusticus. The under-surface is altogether more closely and finely punctate and pubescent and therefore less shining. The scutellum in $C$. ferus is never in the least depressed along the middle; and the sculpture 
and pubescence of the gular area are very different. In $C$. rusticus the tarsi have the third joint divided almost to the base, and the setæ on the eyes are very conspicuous; while in $C$. ferus the eyes appear to be bare, and the tarsal lobes are less perfect.

The species is extraordinarily variable in size, some specimens of the female being quite three times as long as the small males, and are broad in proportion; so that it would take twenty or thirty of the small males to make up the bulk of one of the largest females. There are also some variations in the proportions of certain parts of the body, so that I at first thought there to be more than one species under the name of $C$. ferus. A series from Algeria kindly communicated to me by M. Bedel has convinced me that this is not the case. There is also great variation in size independent of sex, some of the females being six or eight times the bulk of other individuals of the same sex. The distance between the eyes on the under-surface of the head varies somewhat, and correlative with it there is a difference in the sculpture of the gular area. I distinguish the following variety with some doubt, having seen only two examples.

\section{FERUS, var. n. Hispanicus.}

Minor, praesertim angustior, elytris fere ecostatis. Long. of 14, o $16 \mathrm{~mm}$. ; lat. of $q 4 \mathrm{~mm}$.

I have seen only a single pair found at Navalperal in the Guadarrama range by Mr. Champion. They were in company with Nothorhina muricata and are damaged by turpentine. There is a slightly larger specimen from the same locality in the Oberthür collection. The sculpture of the gular area appears to be more rugose and less definite than in other forms of $C$. ferus, but the distinction in this respect from certain other Spanish examples is not great. It would take eight such females to attain the mass of a well-developed female of $C$. ferus.

C. ferus has a very wide distribution, but is rarely met with, and then usually only in one or two individuals. Lapland (Coll. Oberthür from Coll. Thorey); Denmark; S. England; France (various localities including Fontainebleau, in August 1898, Coll. Bedel); Portugal; Spain ; Corsica; Algeria; Piræus, Besika Bay; Caucasus (Leder); Akbès (Coll. Oberthür); Madeira. 
The synonymy of this species is a rather difficult question. The oldest name that certainly applies to it is that given by Dejean in his collection as a var. of $C$. rusticus, and formally published by Mulsant in 1840. C. polonicus, Motsch. (1845), is probably this species. As regards Callidium triste, Fabr., Mant. Ins., p. 154, the brief description gives no special reason for supposing it to be a Criocephalus, except that he likens it to C. rusticus. The C. lugubre, Gmelin, is simply an error; he copies Fabricius' description of $C$. triste, and, as he gives no reason for changing the name, he probably merely wrote "lugubre" in error for C. triste.

The following is therefore the only synonymy for which I can venture to take any responsibility.

Criocephalus rusticus, var. ferus, Dej., Cat. Coll. (not described); Mulsant, Long. France, ed. I, p. 4.

? ? C. coriaceus, Motsch, Bull. Mosc., 1845, i, p. 89.

? C. polonicus, Motsch., l.c., p. 88.

C. epibata, Schiödte, Kroyer Tidskr. (3), ii, p. 521 (1864).

C. ferus, Kraatz, Berlin. ent. Zeitschr., 1863, p. 107, and op. cit., 1872, p. 319 ; Bedel, Faune Col. Seine, v, pp. 23 and 69 .

Criocephalus nubilus, Lec.

Criocephalus nubilus, Leconte, J. Ac. Philad., ser. 2, II, p. 36.

This species has strong punctuation on the elytra like C.rusticus; the tarsi have moderate lobes like C. pinetorum. The labrum, I believe, brings the species in the $C$. ferus group. The sculpture of the gular area is coarse and deep, but occupies only a small area. The eyes bear long setæ. The prosternum is slightly convex in front.

Hab. N. America.

N.B.-The North American Criocephalus require a thorough revision, for which the material does not exist in this country, so far as I know. Leconte, new species North American Coleoptera, Part II, 1873, gives no less than seven species as North American. He divides the genus into two groups: (1) tarsi feebly lobed, C. productus, C. agrestis and C. asperatus; (2) tarsi deeply divided with long lobes, C. montanus, n. sp., C. obsoletus, C. nubilus, C. australis. The matter stands practically as he thus left 
it thirty years ago. C. montanus is perhaps a variety of C. nubilus. C.obsoletus and C. mexicanus are treated in the British Museum collection by Mr. Gahan as being the same species, and he is probably right. C. austratis I do not know; it is probably another genus, as suggested by Leconte.

In the Bull. Brooklyn Soc., vol. vii, 1884, pp. 63, 64, there is given a table of the North American Criocephalus, but it is not of any importance. It is taken from Leconte; and some synonymy is added that is apparently taken from the Munich Catalogue; there is also a figure of "C. productus," which is certainly not representative of that species, but is more like C. asperatus.

C. nubilus differs from the first Lecontian group of species by having shorter hairs on the metasternum, and longer setæ on the eyes. It differs from $C$. tibetanus by the less transverse thorax and the much larger lobes of the tarsus.

\section{Criocephalus tibetanus, $\mathrm{sp} . \mathrm{n}$.}

१. Major, fusco-niger opacus, prothorace sat transverso, elytris bicostatis, fortiter punctatis. Long. $24 \mathrm{~mm}$., lat. $6 \frac{3}{4} \mathrm{~mm}$.

Although this insect looks like $C$. rusticus, and has sculpture similar thereto, it is allied to $C$. ferus. No setæ are visible on the eyes, there is a bush of erect pubescence on the gular area, and the third tarsal joint is only slightly bilobed. The labrum I have not been able to examine, so that the position of the species is doubtful. The gular area is not definitely limited behind, it is very broad, densely sculptured, rugose in front, rather finely punctured behind.

\section{Hab. Tibet.}

The type is in the British Museum, and was found in East Tibet by one of the collectors of the late Mr. J. H. Leech. A very similar insect from Tibet is the $C$. deceptor described on a previous page.

\section{Criocephalus exoticus, sp. n.}

§. Angustus, niger, prothorace haud transverso, profunde biimpresso ; elytris obsoletissime costatis et punctatis. Long. $17 \mathrm{~mm}$., lat. $5 \mathrm{~mm}$.

Described from a single male in bad preservation in the collection at the British Museum. The eyes have no long 
hairs. The gular area is deeply rugosely punctate, and bears a bush of long black hair. The front of the prosternum shows some deep rugae. The second joint of the antennæ is elongate, about as long as the first joint. The third joint of the tarsus is very little emarginate. Structure of labrum not definitely ascertained. The species is no doubt quite distinct; it looks like the North American C. agrestis or productus, but appears to be nearer to C. ferus, notwithstanding the intense black colour of the male.

Hab. NoRth Chin Hills, Burma. Lieut. Watson in 1894.

\section{Criocephalus agrestis, Kirby.}

Angustus, sat elongatus niger, elytris fusco-nigris; prothorace bi-impresso ad latera vix angulato; elytris bicostatis, inter costas subtilissime sculpturatis. Long. $18 \frac{1}{2} \mathrm{~mm}$., lat. $5 \mathrm{~mm}$.

This North American insect in the male sex greatly resembles C.ferus; it is rather more slender and shining, and has a smaller thorax, which has a very slight angular prominence at each side of the middle. I can give no information as to the distribution of this species in North America.

\section{Criocephalus productus, Lec.}

Gracilis, elongatus, niger, elytris maris dilutioribus; prothorace haud transverso, disco inaequali, tri- vel quadri-impresso, ad latera subangulato ; elytris elongatis, costatis, inter costas crebre perspicue punctatis. Long. 20-26 mm., lat. $4 \frac{7}{8}, 6 \frac{1}{2} \mathrm{~mm}$.

Readily distinguished from $C$. agrestis by the more elongate form, the less transverse thorax and the more developed sculpture of the elytra. The sculpture of the gular area consists of fine rugosities, and there is not nuch beard.

\section{Hab. N. America.}

The species is, I believe, not uncommon in N.W. North America. I have specimens from Montana (Morrison); Vancouver (Mathew); California (Hepburn).

\section{Criocephalus asperatus, Lec.}

Latior, robustus, niger, elytris interdum dilutioribus ; prothorace disco inæquali, ad latera numerose muricato-asperato, lateribus angulatim prominalis; elytris bicostatis, sculptura inter costas obsoleta ; antennis articulis ultimis quatuor abbreviatis. Long. $21-27 \mathrm{~mm}$., lat. $7 \frac{1}{4} \mathrm{~mm}$. 
This very distinct species cannot be mistaken for any other, the structure of the antennæ being very peculiar. The terminal four joints are abruptly shorter than the preceding, the eighth joint being scarcely half as long as the sixth. There is not much difference between the sexes. The male has the legs and antennæ rather thicker and the terminal joints of the latter not quite so abbreviate. The bush of hair on the gular area is very remarkable in this species. And the clypeus is considerably larger than in any other species; in this last character it approaches the genus Megasemum.

Apparently common in N.W. North America; it extends at any rate from Montana in the north of the United States to Guaymas in Northern Mexico (Mathew).

\section{I.ARVE.}

We have found larvæ of at least three species of Longicorn Coleoptera in the wood of the Scotch fir-trees in the New Forest, viz. Rhagium bifasciatum, Asemum striatum and Criocephalus ferus. These three larvæ are extremely similar. The characters of the three forms have been described by Schiödte, so that it is only necessary here to give diagnostic characters. Schiödte and the other writers on the subject have given no information as to the habits of the three larvæ, and as these exhibit very striking differences, Mr. Smith's notes on this subject will doubtless be acceptable to a wide circle of entomologists.

The three larvæ, as already stated, are of three different genera, Asemum, Criocephalus and Rhagium. Mr. Smith has never met with all three contemporaneously associated, but Asemum is frequently found in the same stumps as Rhagium; and in the trees in which Criocephalus has been found in this country it is also associated with Asemum.

Notwithstanding the extreme resemblance of the three larvæ, they may be readily distinguished by the spines at the anal extremity of the body. In Rhagium there is only one spine (Plate IX, fig. 9); in Asemum there are two spines placed near one another and divergent (Plate IX, fig. 8); in Criocephalus there are two spines placed at a little distance from one another (Plate IX, fig. 7) and parallel, or even at the tips very slightly convergent. In profile the two Asemum spines are straight; in Criocephalus they are slightly directed upwards.

TRANS. ENT. SOC. LOND. 1905.-PART I. - (MAY) 
Asemum larva. The description and figures given by Schiödte (Naturalist. Tidskr. (3) x, Plate xiv, pp. 443) are correct so far as they go, but he has given of the whole larva, and in his figure of the head has omitted all details of sculpture and clothing. We have not been able to find any other drawing of Asemum larva, and have therefore given a figure (Plate IX, fig. 6). Beyond the character we have already mentioned, drawn from the spines, there are only very slight marks of distinction from the larva of Criocephalus; Asemum larva has the surface slightly more shining, the upper-surface of the head is conspicuously shining, its colour is paler, and the whole head is less robust and powerful than it is in Criocephalus.

Criocephalus ferus larva (Plate IX, fig. 5). Larva of Criocephalus has been described by Schiödte, and some of its parts figured by him, t. c., Plate xiii, figs. 11-19. His species he considered to be $C$. rusticus, and, notwithstanding the confusion that has existed for so many years as to $C$. ferus and C. rusticus, there is little doubt that he was correct in his determination. The larva of C.ferus, as found in the New Forest, agrees very closely with Schiödte's description of $C$. rusticus. If actual comparison could be made of the two larvæ some distinctions would probably be found. The head of $C$. ferus larva appears to be shorter than Schiödte's figure, the part behind the clypeus especially shorter, and destitute of the peculiar lobe-like marks shown in Schiodte's figure.

The larvæ of Asemum striatum (fig. 6) and of Cricocephalus ferus (fig. 5) resemble one another extremely. $C$. ferus larva is much larger when full-grown; it attains a length of $30 \mathrm{~mm}$. or more, and a width across the thorax of 9 or $10 \mathrm{~mm}$; the terminal segments are more ample; the mandibles and margin of the head are black; the chitinized patches-darker in colour-are more definite and conspicuous; the under-side of the head is rough and pubescent, and darker in colour than in Asemum; the antennæ are shorter in comparison; the two short spines placed at a little distance from one another (Plate IX, fig. 7) at the extremity of the body are, as already pointed out, diagnostic. The spiracles of the Criocephalus larva are more elongate (less circular) than they are in Asemum. There is a good deal of difference in the way these two larvæ distend their segments for the purpose of 
progression in their burrows, and for working at their excavation.

Rhagium bifasciatum. This larva is abundant in the New Forest, and unlike the larvæ of Criocephalus and Asemum is easily obtained owing to its totally different habits. The Rhagium lives only in the soft wood that has commenced to decay.

I will here call attention to a very remarkable variation that has been detected by Mr. Gahan during the progress of this memoir. By the courtesy of the Director of the British Museum (Natural History) I am able to figure it. I have in the preceding pages formed the group Criocephalinx for certain forms that have only one spur on the front tibia (Plate IX, fig. 14), instead of two as is usual in the Cerambycidæ (Plate IX, fig. 13). In the British Museum collection Mr. Gahan has detected a female Criocephalus rusticus having two spurs (Plate IX, fig. 15) on the tibia of the left front-leg. Unfortunately the right front-leg is missing in this specimen, but when the individual was first observed it possessed both anterior legs, and Mr. Gahan and myself are pretty certain that both legs possessed the two spurs.

There appears to be nothing else abnormal about this individual. It may be described in brief as a specimen that departs from charact $r$ of its species, genus and tribe; taking on the character of another tribe. The character abnormal in this specimen is normal in Cerambycid Coleoptera generally.

It would be almost useless to discuss the nature of this variation without further information. Some will see in it a case of "reversion." Mr. Punnett has suggested to me that it is probable that other specimens similarly "abnormal" may be found in the locality where this $\dot{C}$. rusticus comes from, and if so the case might be viewed as one of more continuous heredity.

On the other hand, it must not be forgotten, that two spurs are normal on the other legs of Criocephalus; so that it is possible to view the abnormality as a case of homœotic variation (Bateson).

Summary of changes and additions made in the preceding paper:-

Criocephalinx, new group separated from Aseminx.

Cephalallus, n. g., C. oberthuri, n. sp., Yurınan. 
Megasemum, defined and male of M. 4-costatum described. Cephalocrius, n. g. for Crio. syriacus, Reitter.

Criocephalus pinetorum, Woll., established as a valid species. Female described for first time.

C. deceptor, coreanus, tibetanus, exoticus, n. spp.

C. ferus, var. hispanicus, n. var.

C. obsoletus, Rand.=(mexicanus, Th.), n. syn.

C. rusticus, description of an aberration.

\section{Explanation of Plate IX.}

Fig. 1. Under-side of head of Criocephulus ferus.

2. " " " " , rusticus.

3. Labrum of " ferus.

4. $", \quad, \quad$ rusticus

5. Larva of Oriocephalus ferus nearly full-grown.

6. " "Asemum striatum, profile.

7. Spines terminating the body of larva of Criocephalus ferus seen from above and in profile.

8. Do. do. Asemum striatum.

9. Spine terminating body of larva of Rhagium seen from above.

10. Portion of larva of Criocephalus ferus, showing form and position of spiracles and the vestigial legs.

11. One of the legs more highly magnified.

12. Egg of Criocephalus ferus.

13. Portion of front-leg of Asemum striatum o showing the two spurs.

14. Portion of front-leg of Criocephalus rusticus of showing the single spur.

15. Portion of front-leg of Criocephalus rusticus $q$ abnormal specimen from Amanus mountains, showing the existence of two spurs as in Asemum. 


\section{$2 \mathrm{BHL}$ Biodiversity Heritage Library}

Smith., F Gilbert. 1905. "VII. The genus Crioceplialus.By D. Sharp, M.A., F.R.S. With Notes on the habits of Asemum striatum and Crioceplialus ferus." Transactions of the Entomological Society of London 53, 145-164. https://doi.org/10.1111/j.1365-2311.1905.tb01157.x.

View This Item Online: https://www.biodiversitylibrary.org/item/51242

DOI: https://doi.org/10.1111/j.1365-2311.1905.tb01157.x

Permalink: https://www.biodiversitylibrary.org/partpdf/35462

\section{Holding Institution}

Smithsonian Libraries

\section{Sponsored by}

Smithsonian

\section{Copyright \& Reuse}

Copyright Status: Public domain. The BHL considers that this work is no longer under copyright protection.

This document was created from content at the Biodiversity Heritage Library, the world's largest open access digital library for biodiversity literature and archives. Visit BHL at https://www.biodiversitylibrary.org. 